\title{
Notícias sobre TV: - Diário de S. Paulo e a cobertura sobre a implantação da PRF-3-TV-Tupi de São Paulo
}

\section{Noticias sobre TV: el Diário de S. Paulo y la cobertura informativa sobre la im- plantación de la PRF-3-TV de São Paulo}

\section{Mônica Rodrigues NUNES}

Resumo: O presente artigo faz uma recuperação histórica, a partir da cobertura jornalística realizada pelo Diário de S. Paulo - jornal da cadeia dos "Diários Associados" de Assis Chateaubriand -, sobre a implantação da primeira estação de televisão de São Paulo, a PRF-3-TV-Tupi. O período estudado é o do ano de inauguração da televisão no Brasil - de $1^{\circ}$ de janeiro a 31 de dezembro de 1950. Da leitura do periódico podem ser retiradas algumas informações sobre a instalação e as primeiras programações da televisão no país. Nas matérias do jornal sobre o tema, nota-se a presença de seis temas principais: alcance da TV; equipamentos e montagem; receptores de TV; transmissões experimentais; inauguração da televisão; e programação.

Palavras-chave: Diário de S. Paulo; PRF-3-TV-Tupi; TV na Taba; transmissões experimentais; transmissões regulares; programação.

Resumen: El presente artículo hace una recuperación de la memoria histórica, de la cobertura informativa hecha por el Diário de S. Paulo - periódico de la cadena de periódicos y emisoras de radio ("Diários Associados") de Assis Chateaubriand -, sobre la implantación de la primera estación de televisión de São Paulo, la PRF-3-TVTupi. El período estudiado es del año de inauguración de

1 Jornalista, Mestre (2003) e doutora (2007) em Comunicação Social pela Universidade Metodista de São Paulo, com estágio doutoral na Universidad Complutense de Madrid. Atualmente é professora Adjunto II do Curso de Comunicação Social - Jornalismo, da Universidade Federal de Uberlândia (UFU). E-mail: monicarodriguesnunes@, gmail.com la televisión en Brasil - de $1^{\circ}$ de enero a 31 de diciembre del 1950. De la lectura del periódico se pude sacar algunas informaciones sobre la instalación y las primeras programaciones de la televisión en Brasil. En las materias del periódico sobre el tema, se nota la presencia de seis temas principales: alcance de la TV; equipos y montaje, receptores de TV; transmisiones experimentales; inauguración de la televisión; y programación.

Palabras clave: Diário de S. Paulo; PRF-3-TV-Tupi; "TV na Taba"; transmisiones experimentales; transmisiones regulares; programación.

\section{A TV no jornal}

Desde a inauguração das primeiras emissoras de televisão no mundo, revistas - principalmente aquelas especializadas em cinema e rádio - e jornais brasileiros noticiaram sobre o novo invento. Reportagens, notas, notícias, ensaios, comentários e artigos procuravam informar aos leitores sobre a nova tecnologia, curiosidades, programas, elenco, etc..

Entre as revistas que tiveram a televisão como pauta, antes mesmo da inauguração da primeira emissora brasileira, está a Cinearte que passou a editar desde a década de 1930 diversas páginas sobre o tema; sendo o primeiro texto "Agora, a televisão", publicado na edição 283 de 1931. Entre os jornais paulistanos, um exemplo é a série de ensaios, intitulada "Daguerreotipo ou televisão", assinada por José Geraldo Vieira, no Suplemento Literário da Folha da Manhã, durante o ano de 1947.

Na década de 1940, os veículos impressos dos "Diários Associados" passaram a publicar textos sobre o funcionamento e características de emissoras de televisão em atividade na Europa e nos Estados Unidos, além de informar sobre as negociações e compra dos equipamentos para a montagem das primeiras emissoras de televisão brasileiras.

A história da televisão no Brasil começou a esboçar-se quando Chateaubriand ao ver, nos escritórios da RCA Victor em New York, em 1946, a televisão em pleno funcionamento, decidiu comprar equipamentos para a montagem de duas emissoras de TV: uma no Rio de Janeiro e outra em São Paulo.

Para a compra do equipamento de TV para São Paulo, Chateaubriand depositou, em 1947, a primeira parcela (duzentos mil dólares) na conta bancária da RCA e, ficou por mais de dois anos no aguardo do envio do transmissor. Ao mesmo tempo acertou com a General 
Electric a compra de equipamento similar para a TV Tupi do Rio de Janeiro, uma vez que a RCA havia pedido prazo ainda maior para a entrega de um segundo transmissor.

Sobre os recursos para a compra dos equipamentos para as emissoras do Rio de Janeiro e de São Paulo, Assis Chateaubriand escreveu, em artigo publicado no Diário de S. Paulo, em 31 de agosto de 1950, que só foi possível graças ao apoio da iniciativa privada, especificamente das empresas: Wolff, Sul América Seguros, Sams (lãs do Moinho Santista) e Guaraná Champagne (Antarctica). Alguns dias depois, em 22 de setembro, Chateaubriand trazia a seguinte informação:

Ao sentirmos madura a televisão nos Estados Unidos e na Inglaterra, pedimos àqueles quatro anunciantes nossos que, em vez de nos entregarem autorização de publicidade por três meses, demonstrassem um pouco mais de confiança em nossa estabilidade. E eles nos deram suas ordens de inserção de anúncios por doze e dezoito meses. Munidos dessas ordens fomos aos bancos que trabalham conosco, descontando autorização de publicidade, por antecipação. Fizemos de três golpes, para adquirir e montar dois equipamentos, do Rio e São Paulo, dezesseis milhões de cruzeiros, o que não é ainda uma terça parte do custo do negócio.

Enquanto os trâmites para a implantação das primeiras emissoras de televisão eram acertados, a direção dos "Diários Associados" utilizou alguns de seus veículos de comunicação para informar sobre a chegada desse novo veículo ao país.

De propriedade dos Diários Associados, na capital paulista, circulavam com destaque, nas décadas de 1940 e 1950, a revista Cruzeiro e os jornais Diário da Noite e Diário de S. Paulo. O vespertino Diário da Noite foi fundado, em sete de janeiro de 1925, por um grupo de jornalistas formado por Leo Vaz, Oswaldo da Costa, Antonio Figueiredo, Plínio Barreto e Rubens do Amaral. No entanto, poucos meses após o lançamento, este jornal, por motivos financeiros, foi colocado a venda. Interessando em iniciar novos empreendimentos em São Paulo, Assis Chateaubriand, que já era proprietário do periódico $O$ Jornal do Rio de Janeiro (adquirido em 1924), comprou o Diário da Noite.
Afirma Fernando Morais (1994, p. 153-4) que, "no dia dois de junho de 1925, embora o nome ainda não aparecesse no cabeçalho nem no expediente, o Diário da Noite era propriedade de Chateaubriand, que manteve Plínio Barreto e Rubens do Amaral como diretores e Leo Vaz como redator-chefe". Completa este autor, que menos de seis meses após mudar de mãos, o jornal apresentava ótimos lucros (MORAIS, 1994, p. 170). Dois anos depois, este periódico passou a ser administrado por Oswaldo Chateaubriand e foi, neste período, que teve sua linha editorial definida: jornal popular, feito para as massas.

Com o desejo de ampliar sua rede de veículos impressos ${ }^{2}$, Assis Chateaubriand preparou em sigilo um novo projeto para a cidade de São Paulo. Tratava-se do lançamento do Diário de S. Paulo, um jornal feito para a elite paulistana, que buscava semelhança com o jornal americano The New York Times. Sua estreia foi em cinco de janeiro de 1929.

Editado de terça a domingo, o Diário de S. Paulo começou a circular com tiragem considerável para o período, chegando a imprimir 90 mil exemplares. Já no seu lançamento, este jornal inovou ao publicar as páginas organizadas em editorias, e desde o início buscou dar espaço para as artes e a literatura (NUNES, 2007). Em sua primeira semana de circulação lançou um suplemento literário, e a partir de 17 de março de 1929, passou a publicar a Revista de Antropofagia - Segunda Dentição.

Como dito anteriormente, tanto o Diário de $S$. Paulo quanto o Diário da Noite permaneciam em circulação na década de 1950. Mas foi o primeiro deles que passou a trazer, mais frequentemente, para o público paulista, informações sobre a televisão no mundo e no Brasil. Entre outros textos publicados neste jornal, logo que as primeiras sinalizações da compra dos transmissores foram confirmadas, Chateaubriand, que assinava diariamente um artigo na primeira página do Diário de $S$. Paulo, passou a informar os leitores sobre a compra e a instalação das primeiras emissoras de TV no Brasil.

De primeiro de janeiro a 31 de dezembro de 1950 localizamos, no Diário de S. Paulo, cerca de $80^{3}$ textos abordando o tema televisão em São Paulo. Estes eram editados em diferentes partes do jornal - desde a capa até o Suplemento Dominical ${ }^{4}$. Muitas matérias eram acom-

2 Neste período já estavam em circulação, O Jornal no Rio de Janeiro, o Diário da Noite em São Paulo, o Estado de Minas em Belo Horizonte e a revista Cruzeiro.

3 Para o presente artigo consultamos todas as edições do Diário de S. Paulo no Arquivo do Estado de São Paulo. Em 1950, este jornal era editado de terça-feira a domingo.

4 Segundo definição do próprio Diário de S. Paulo. "Suplemento: dezesseis páginas em três cores que valem por uma revista". Nele havia, 
panhadas por fotografias, ajudando a ilustrar os passos para a implantação da TV nesta cidade. Deve-se ressaltar aqui, a presença de muitas notas publicadas na coluna "Cidade do Rádio", assinada por Ayrton Rodrigues.

Os textos publicados no Diário de S. Paulo permitem entender aspectos da montagem da PRF-3-TV (ou TV Tupi de São Paulo) e da produção da programação exibida nas transmissões experimentais e das primeiras transmissões regulares. Através de análise de conteúdo verificamos a presença de seis assuntos principais para o tema televisão em São Paulo: alcance da TV; equipamentos e montagem; receptores de TV; transmissões experimentais; inauguração da televisão; e programação.

Curiosamente, em breve leitura de outros diários $^{5}$, em circulação na capital paulista, em 1950, verifica-se a ausência de informações sobre a implantação da primeira emissora de TV na capital paulista. No entanto, paulatinamente o assunto passou a ser pauta em alguns jornais, que publicavam informações sobre a programação da PRF-3-TV. Entre eles o Jornal da Tarde, que logo após o início das transmissões regulares, lançou a seção "Cartaz: Cinema-teatro-televisão-circo".

Não podemos deixar de ressaltar que os dados coletados das páginas do jornal, em certa medida, demonstram a percepção/visão do responsável pela implantação da TV em São Paulo, uma vez que Chateaubriand era proprietário do Diário de S. Paulo e da PRF3-TV. Também é preciso considerar que a utilização do jornal impresso como fonte básica para o levantamento dos dados, em particular, da programação, é limitado. Isto porque não é possível confrontar as informações divulgadas com os programas efetivamente colocados no ar.

\section{O alcance da TV em São Paulo}

Desde o início das negociações para a compra de transmissores de TV para serem instalados em São Paulo e no Rio de Janeiro, Chateaubriand demonstrou preocupação com o alcance da TV. Chegou, inclusive, a solicitar a presença de peritos para que fizessem um estudo sobre o sinal da TV de São Paulo.

Segundo Chateaubriand, em artigo publicado no Diário de S. Paulo, em 31 de agosto de 1950, técnicos da Marconi Wirelles Corporation, em visita à capital paulista em 1947, foram totalmente céticos quanto às pretensões

além da publicação de contos, reportagens e entrevistas, as seguintes seções: Films e Estrelas; Rádio; Teatro; Livros, leitores e autores; e Ciência Popular.

5 Em 1950, além dos jornais Associados, circulavam, entre outros, em São Paulo: Folha da Manhã, Folha da Tarde, Folha da Noite, A Gazeta, Correio Paulistano e O Estado de S. Paulo. de se chegar o sinal da TV a Jundiaí, Santos e Campinas. O desejo de que a TV pudesse alcançar essas cidades foi um dos motivos pela demora em assinar o contrato com a RCA (mais de um ano e meio). Em outro artigo, de 22 de setembro de 1950, Chateaubriand informava que, em 1947 o raio de alcance da TV era de 20 milhas. O transmissor recebido pela TV Tupi de São Paulo, em 1950, era de $5 \mathrm{KW}$, semelhante aos instalados nos Estados Unidos, alcançando 80 milhas. E acrescentou:

Felizmente, o nosso amigo Brunnet guardou, durante perto de três anos, os primeiros duzentos mil dólares que lhe entregamos, esperando maiores inovações no campo das distâncias a cobrir pela televisão. (...) Aí temos, depois de 32 meses do pagamento do sinal da compra do transmissor paulista, o acontecimento inesperado: a curva da Serra, de Cubatão para Santos, e o paredão da Serra dos Cristais, que se interpõe entre São Paulo, Jundiaí e Campinas, não constituem mais obstáculos para entrada do nosso sinal nas três cidades-satélites desta capital.

\section{3}

Entre agosto e setembro de 1950, transmissões experimentais foram vistas com nitidez nas cidades de Campinas, Jundiaí e Santos ${ }^{6}$. Assim como na capital, receptores eram colocados em locais públicos no horário das transmissões: das $17 \mathrm{~h}$ às $19 \mathrm{~h}$. Desta forma, antes mesmo da inauguração definitiva, a PRF-3-TV chegava a lugares distantes dos estúdios dos Diários Associados.

Para que a TV Tupi pudesse alcançar além das cidades citadas, ou um raio maior que $75 \mathrm{~km}$, era preciso instalar subestações. O local escolhido para montagem da antena da TV em São Paulo foi o prédio do Banco do Estado, na época, um dos edifícios mais altos da América do Sul.

6 Após a inauguração definitiva da TV, o Diário de S. Paulo publicou, em 05 de outubro de 1950, que o sinal da TV chegava a Brangança/ SP. 


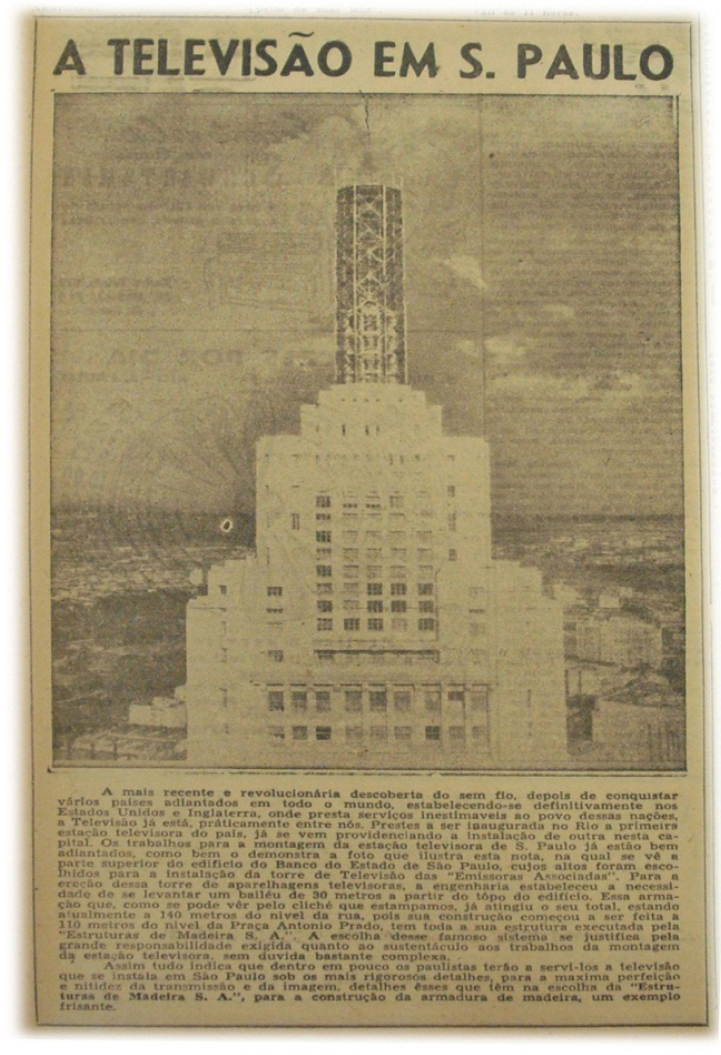

Fig.01: Antena da PRF-3-TV no alto do Banco do Estado.

“A televisão em São Paulo” (DSP, 25/06/1950)

A preocupação com o alcance da TV, possivelmente, tinha motivo econômico. Se este empreendimento era uma aventura cara e o retorno do investimento uma incógnita, o seu alcance seria a possível saída para algum retorno financeiro. Quanto maior o alcance do sinal da TV, maior seria o público potencial, aumentando as chances de empresas investirem em anúncios publicitários.

Não por acaso, os responsáveis pelo Diário de $S$. Paulo noticiaram, em 29 de dezembro de 1950, o primeiro contrato de publicidade da TV onde havia a seguinte informação: "o advento da televisão em São Paulo, com a PRF-3-TV, trouxe aos anunciantes a forma mais completa e eficiente de publicidade existente no mundo. A transmissão de imagem à distância acompanhada do som”. Os primeiros anúncios em vídeo veiculados pela TV de São Paulo, a partir de $1^{\circ}$ de janeiro de 1951, seriam das firmas varejistas "Tecidos Princesa" e "União Comercial de Tecidos”, dos irmãos Emílio, Willian e Jean Haidar.

\section{Equipamentos e montagem da PRF-3-TV}

Embora a entrega do transmissor, pela RCA, para montagem da PRF-3-TV tenha sido anunciada por Chateaubriand em 16 de outubro de 1949, o embarque do equipamento ocorreu apenas em 11 de janeiro do ano seguinte.

A bordo do cargueiro "Mormacyork", vinte e quatro toneladas, referente ao aparelhamento completo para montagem da TV, foram enviadas da Filadélfia ao porto de Santos em São Paulo. No carregamento estavam, entre outros: antena tripla (SuperTurnstile), carros retransmissores (unidades móveis de televisão), câmeras, antenas parabólicas, dois projetores de filmes de $16 \mathrm{~mm}$.

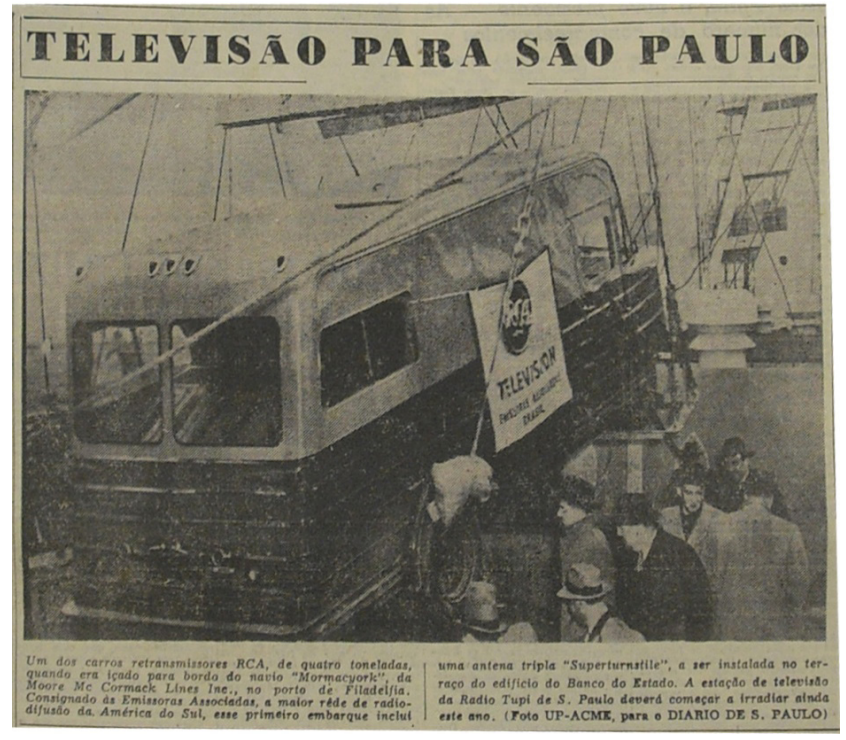

Fig.02: Parte do equipamento da PRF-3-TV no Porto da Filadélfia.

“Televisão para São Paulo” (DSP, 19/01/1950)

A chegada dos equipamentos, ao Brasil, para a montagem da primeira estação de televisão de São Paulo ocorreu em $1^{\circ}$ de fevereiro de 1950 . Cerca de 210 volumes foram descarregados e armazenados na Companhia Docas no porto de Santos.

Para a ocasião, Chateaubriand preparou uma série de eventos e convidou autoridades e artistas para participar de um coquetel, a abordo do navio, e para um almoço no Parque Balneário Hotel, em Santos. 


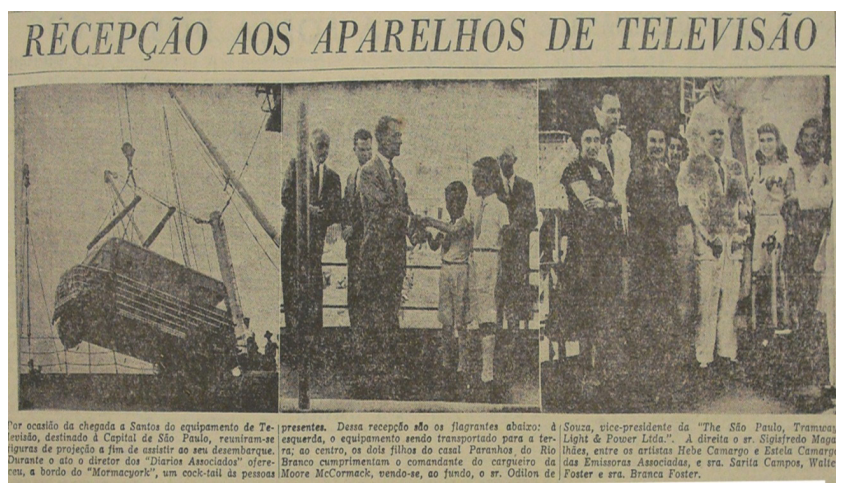

Fig. 03: Chegada a Santos do equipamento da televisão. "Recepção aos aparelhos de televisão" (DSP, 05/02/1950)

Para festejar a chegada do equipamento a Rádio Tupi ofereceu, no dia 2 de fevereiro, um show no Teatro Coliseu em Santos. Artistas do elenco desta emissora e convidadas internacionais, como a cantora portuguesa Amália Rodrigues e a dançarina cubana Rayito de Sol, se apresentaram em recital que teve início às $23 \mathrm{~h}$.

$\mathrm{O}$ aparelhamento para a montagem da primeira emissora de TV de São Paulo permaneceu por 56 dias no porto de Santos aguardando as formalidades alfandegárias para o seu desembaraço. Em 24 de março de 1950, quatro caminhões, com a viatura de televisão à frente, formaram uma frota, que tomou rumo a São Paulo pela Via Anchieta.

Com a chegada do equipamento de TV à capital, o Diário de S. Paulo passou a publicar uma série de reportagens sobre o assunto. Em geral, o enfoque das matérias apontava para uma nova conquista, o desenvolvimento das comunicações, através do moderno meio de transmissão de imagem à distância, que estaria ao alcance da população de São Paulo.

Dois meses após a chegada do equipamento a São Paulo deu-se início à instalação da torre da TV. A montagem foi realizada por técnicos brasileiros formados nos Estados Unidos e por engenheiros e técnicos americanos e ingleses enviados pela RCA. A montagem da torre foi concluída na primeira quinzena de julho.

Ao mesmo tempo em que a torre transmissora era instalada no alto do Banco do Estado, Chateaubriand mandou construir um estúdio de televisão no alto do Sumaré ao lado das emissoras de rádio Tupi e Difusora que formavam o complexo denominado "Cidade do Rádio". Sua conclusão ocorreu em agosto de 1950.

\section{Receptores de TV}

Até julho de 1950, os televisores que existiam na capital paulista eram de propriedade dos "Diários Asso- ciados". Nos textos analisados, não há informação sobre a quantidade deles; apenas quando da estreia do serviço de televisão, com a transmissão do show de Frei Mojica, em 7 de julho de 1950, foi publicado que dois aparelhos haviam sido colocados no hall do Edifício Guilhermina Guinle.

Alguns autores, entre eles Sérgio Mattos (2000, p.92), afirmam que Chateaubriand teria contrabandeado 200 receptores para que as irradiações da TV pudessem ser conhecidas pelo público paulista. No entanto, nas matérias publicadas no Diário de S. Paulo não há pistas sobre este feito. $\mathrm{O}$ que se verifica é que logo que o equipamento para montagem da PRF-3-TV chegou ao Brasil, uma reportagem, publicada na edição de 09 de fevereiro de 1950, trazia informações sobre a importação de aparelhos receptores de TV.

Em entrevista, o proprietário das lojas Cassio Muniz, Helio Muniz, avisava que seriam importados três mil aparelhos RCA de 10 polegadas e que estes chegariam ao Brasil em cinco ou seis semanas; fato que só ocorreu em 22 de julho de 1950. Tratava-se do primeiro carregamento do gênero que chegava a São Paulo.

Este primeiro lote de receptores marca um momento importante na implantação da televisão em São Paulo. Somente depois dele, é que foi possível iniciar as transmissões experimentais, em caráter regular, em São Paulo, permitindo, também, testar o alcance do sinal da TV nas cidades vizinhas de Santos, Jundiaí e Campinas.

Ao noticiar a chegada dos primeiros receptores de TV, em 23 de julho de 1950, o Diário de S. Paulo publicou:

\footnotetext{
A Televisão acaba de entrar em sua primeira fase de expansão geral: um carregamento de grande número de aparelhos receptores RCA, totalizando mais de seis mil quilos de peso foi desembarcado ontem à noite em Congonhas, de bordo de dois cargueiros especiais da Panair Do Brasil.
}

O número de aparelhos que chegaram no carregamento, importado pelas lojas Cassio Muniz, não foi mencionado na reportagem do Diário de S. Paulo. O que se nota, pelos anúncios publicados, neste jornal, é que o número de receptores à venda em São Paulo, antes da inauguração oficial da televisão, era expressivo. Isto porque, além da loja Cassio Muniz, havia pelo menos dois outros estabelecimentos comercializando televisores, com entrega imediata, em setembro de 1950.

\section{5}


No dia anterior à inauguração da TV, dois anúncios foram publicados na capa do Diário de S. Paulo: de H. Lopes Importador e da loja Natal Eletrica Ltda. Nesta última, o anúncio trazia o seguinte texto: "assista confortavelmente em seu lar o selecionado programa inaugural da PRF-3-TV amanhã, adquirindo magnífico receptor General Eletric".

O valor dos receptores de TV era bastante alto - principalmente se comparado ao do rádio - compatível com o das luxuosas rádio vitrolas. Os modelos de mesa custavam em torno de $\mathrm{Cr} \$ 10.950,00$ e os de "console", mais suntuosos feitos em mogno, cerca de Cr $\$ 12.950,00$. Os preços também variavam de acordo com o número de polegadas, com telas de 10,14,16, 19 e 20.

Uma curiosidade é a variedade de marcas de aparelhos de TV disponíveis no mercado paulistano em 1950. Eram vendidos a pronta entrega modelos da General Electric, RCA-Victor, Philco e Admiral. E até dezembro deste ano, mais lojas passaram a anunciar no Diário de S. Paulo a venda de receptores. Entre elas: Casa São Nicolau, S. Paulo Elétrica, Philco Rádio e Televisão S.A. e Radio Greif.

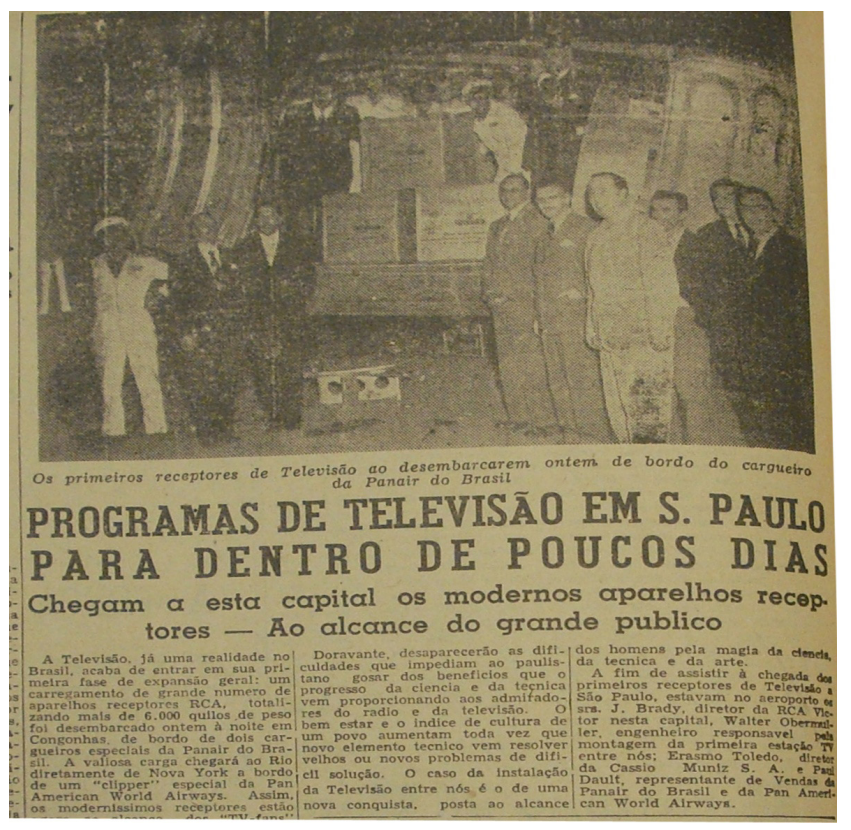

Fig. 04: Chega a São Paulo o primeiro carregamento de receptores de TV.

"Programas de televisão em S. Paulo para dentro de poucos dias" (DSP, 23/07/1950)

Não fosse a falta de aparelhos receptores, possivelmente as transmissões experimentais regulares tivessem iniciado um mês antes. Isto porque, tecnicamente a PRF-3-TV tinha condições de realizar transmissões em longa distância a partir de meados de julho, quando a montagem da torre da TV já havia sido concluída. Parece pouco provável que 200 aparelhos receptores tenham sido contrabandeados, número suficiente para dar início às demonstrações da televisão em caráter experimental. Se houve contrabando, deve ter sido de número menos expressivo.

\section{TV: realidade em São Paulo - transmissões ex- perimentais}

A TV chega a São Paulo em um momento de grande desenvolvimento econômico da cidade. De acordo com o censo demográfico de 1950, a população da capital paulista, impulsionada pelo aumento do setor industrial, passou de 2 para 3,5 milhões.

Neste mesmo período, a cidade começou a ganhar proeminência no campo das artes e cultura. Na década anterior, sobretudo após 1945, foram criados, nesta capital, teatros como o TBC (Teatro Brasileiro de Comédia), museus como o MASP (Museu de Arte de São Paulo) e o MAM (Museu de Arte Moderna) e a Companhia Cinematográfica Vera Cruz. O rádio vivia sua era de ouro, gozando de grande sucesso de audiência com programas de auditório e radionovelas.

Neste contexto, antes mesmo da montagem da TV de São Paulo, notícias alimentavam a imaginação dos futuros telespectadores sobre o novo invento. A televisão era colocada como uma conquista daquele tempo onde o resultado dela era: "cinema, teatro, rádio e mais o jornal combinados” (DSP, 02/02/1950).

Algumas notas e notícias traziam informações sobre o que se poderia esperar da programação televisiva. Entre as novidades estava a possibilidade de assistir, de casa, não apenas programas realizados em estúdios como filmes e shows, mas, também, transmissões de jogos de futebol e outros acontecimentos esportivos como turf. Outra novidade era a telenovela, que seria transmitida pela PRF-3-TV. "Não apenas 'ouvir', mas 'ver' novelas. Elas não serão apenas vozes, diálogo e ruídos, que o ouvinte tem que completar a imaginação" (DSP, 12/02/1950).

A TV tornou-se realidade em 7 de julho de 1950. Momento em que a população de São Paulo pôde experimentar a experiência de ver televisão pela primeira vez, através da TV Tupi. A primeira exibição pública - considerada a estreia do serviço de televisão das Emissoras Associadas - foi a transmissão de um show musical do cantor e religioso mexicano Frei José Francisco de Guadalupe Mojica. 
A apresentação aconteceu no auditório do Museu de Arte de São Paulo, no $3^{\circ}$ andar do Edifício Guilherme Guinle (mesmo edifício dos "Diários Associados"), no centro de São Paulo. Para que a população pudesse assistir a primeira exibição da televisão paulista, foram colocados dois aparelhos de TV no hall do Edifício. A transmissão foi assistida, segundo informações publicadas no Diário S. Paulo, em 08 de julho de 1950, por mais de dez mil pessoas que se aglomeraram nos cruzamentos das ruas 7 de Abril e Bráulio Gomes.

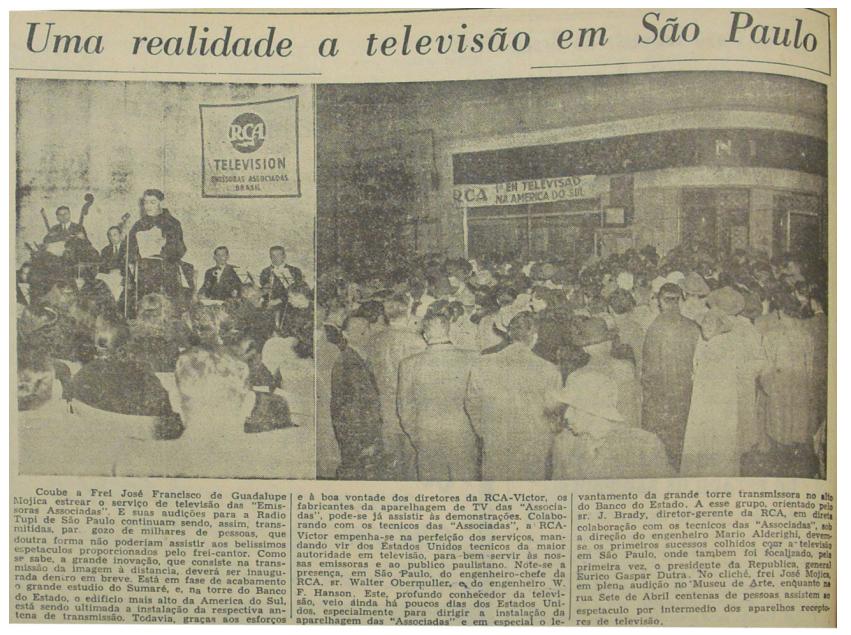

Fig. 05: Primeira transmissão da PRF-3-TV: estreia do serviço de televisão.

"Uma realidade a televisão em São Paulo" (DSP, 12/07/1950)

No dia seguinte à apresentação de Frei Mojica, foi igualmente televisionada a reinauguração do Museu de Arte (localizado no mesmo edifício dos "Diários Associados"). No entanto, estas duas transmissões foram feitas apenas em circuito interno e ao vivo.

Em 16 de agosto de 1950, um mês antes da inauguração definitiva da televisão, a PRF-3-TV passou a transmitir programação regular, em caráter experimental, em longa distância. Neste dia, receptores RCA Victor foram colocados, pela primeira vez, em vários pontos centrais da cidade (entre eles: loja Mesbla, bares, cafés e confeitarias, no hall do Edifício Guilherme Guinle e no hall da Rádio Tupi, no alto do Sumaré) para que o público paulistano pudesse assistir ao primeiro programa de TV transmitido em longa distância. Os aparelhos instalados durante as transmissões experimentais eram dos "Diários Associados" e de lojistas que compraram modelos portáteis ${ }^{7}$ para instalar em seus estabelecimentos.

Enquanto aguardava o momento oportuno para inaugurar oficialmente a televisão, variados programas

7 A partir de 16 de agosto de 1950 a loja Cassio Muniz S. A. começou a vender, na capital paulista, receptores RCA. gravados- filmes produzidos pela equipe da PRF-3-TV, desenhos animados, comédias curtas em película e documentários (fornecidos por consulados e embaixadas) eram transmitidos, de segunda a sábado, das $17 \mathrm{~h}$ às $19 \mathrm{~h}$. A direção destas transmissões era do engenheiro Mario Alderighi, e, na parte artística, o diretor era Cassiano Gabus Mendes.

Durante as transmissões experimentais, fotografias publicadas no Diário de S. Paulo demostram grande interesse popular pela televisão. Onde houvesse um aparelho de TV, curiosos se aglomeravam para conhecer a nova tecnologia.

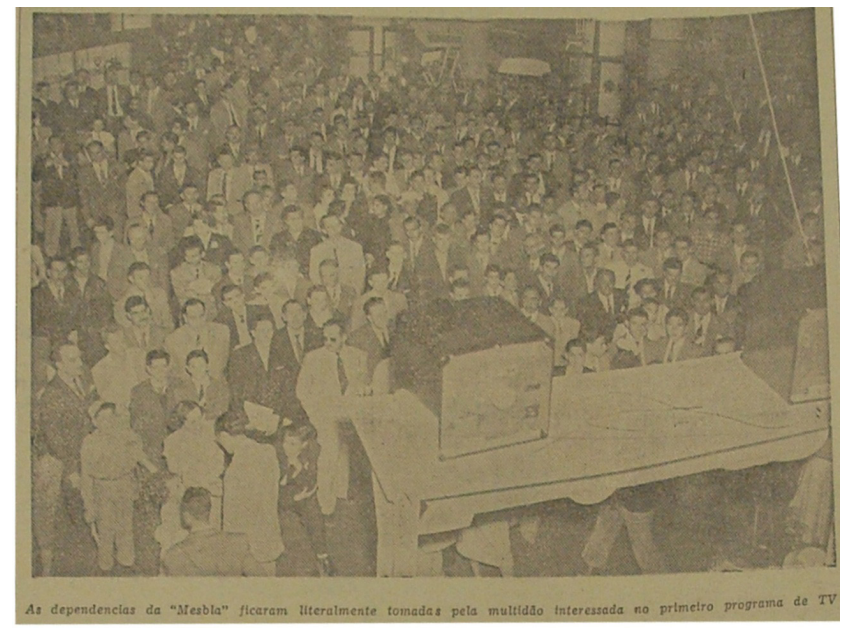

167

Fig. 06: Público assistindo a programação da televisão em estabelecimento comercial. "Iniciou suas transmissões experimentais a PRF-3-TV das Emissoras Associadas" (DSP, 17/08/1950)

\section{Transmissão inaugural da TV}

O Brasil entrou definitivamente na era da televisão, em 18 de setembro de 1950. Nesta data a PRF-3-TV inaugurava oficialmente o seu serviço de transmissão de imagem e som à distância. Inicialmente, Chateaubriand desejava entregar a televisão à população de São Paulo em junho de 1950, quando poderia transmitir a Copa do Mundo, realizada no Brasil.

A conclusão dos trabalhos de montagem da PRF-3-TV no primeiro semestre de 1950 não foi possível devido a uma sequência de acontecimentos, sendo a demora da chegada do equipamento à capital paulista o primeiro deles. A falta de aparelhos receptores e o atraso na conclusão do estúdio de televisão na "Cidade do Rádio" também impossibilitaram o início das transmissões neste período.

Na edição de 18 de setembro de 1950, o Diário da Noite anunciava com destaque na primeira página: "Hoje em São Paulo a Televisão. Sonho que se faz reali- 
dade". Mas esta não era a principal notícia desta edição, pois as manchetes estavam direcionadas para a situação política nacional, às vésperas da eleição presidencial que levaria Getúlio Vargas de volta ao poder.

Já no Diário de S. Paulo, uma série de reportagens foi publicada nos dias que antecederam e sucederam a inauguração oficial da PRF-3-TV. De 14 a 17 de setembro, as matérias buscavam detalhar o programa a ser transmitido no primeiro show da TV; explicavam aos leitores como funcionava uma emissora de televisão (detalhes técnicos, aparelhagens e profissionais necessários); ressaltavam a rapidez da montagem da TV (três meses de trabalhos) e reforçavam o êxito das transmissões, não apenas em São Paulo, mas nas cidades de Santos, Campinas e Jundiaí.

Na descrição do planejamento da transmissão definitiva da TV, constava uma cerimônia de inauguração, com início às $17 \mathrm{~h}$, onde deveriam comparecer autoridades civis, militares e eclesiásticas, representantes da indústria e do comércio, parcela da população e artistas de relevo; e um show de abertura das novas atividades principiando às $21 \mathrm{~h}$, devendo prolongar-se por duas horas ininterruptamente. Toda a transmissão (cerimônia e show de abertura) foi descrita em detalhes, inclusive os enquadramentos utilizados nos planos das câmeras.

A concepção do show inaugural era de Costa Lima e Cassiano Gabus Mendes, direção de Cassiano Gabus Mendes, direção técnica de Mario Alderighi e Jorge Edo, direção musical de Renato Oliveira, regente da orquestra Tupi, e coreografia de Marilia Franco.

Nos dias posteriores à transmissão inaugural da televisão em São Paulo, os textos abordaram os detalhes do show inaugural, intitulado "TV na Taba" (primeiro com transmissão de programas ao vivo), as impressões de personalidades nacionais e estrangeiras (política, eclesiástica, militares e sociedade civil) e mensagens endereçadas às Associadas sobre a inauguração da PRF-3-TV.

Na reportagem "Entregue a São Paulo a TV Associada", de 19 de setembro de 1950, o momento foi definido como "completo êxito tanto artístico quanto técnico", e ainda:

Às 17 horas, na presença de distinto público, foi para o ar o primeiro programa de televisão, anunciado na voz do locutor Homero Silva. Numerosos aparelhos, instalados por toda cidade, registraram o despontar de uma nova era para o broadcasting sul-americano. D. Paulo Rolim Loureiro, bispo-auxi- liar de São Paulo, no palco da televisão, abençoou os estúdios, dirigindo palavras de estímulo aos que promoveram tão auspiciosa criação no rádio brasileiro. Caminhou até à máquina de fixação da imagem, aí aspergindo água benta (...). Com início pouco depois das $21 \mathrm{~h}$ o espetáculo inaugural da TV em São Paulo prolongou-se, ininterruptamente, durante duas horas.

Em 20 de setembro de 1950, Eliézer Burla, autor da seção "Rádio e TV", editada no Diário de S. Paulo, escreveu suas impressões sobre o programa inaugural:

Ligados apenas por simpatia ao pessoal artístico e técnico da Difusora TV, queremos daqui cumprimentá-los pelo seu primeiro programa: cheio de falhas, como era inevitável, mas afinal um programa de televisão. Este programa, dentro de alguns meses ficará enterrado sob os novos que surgirão cada noite, como a pedra fundamental se esconde sob o edifício.

Embora não especifique, em seu texto, quais seriam as falhas ocorridas no dia da inauguração, Burla poderia estar se referindo à necessidade de improvisação na execução de algumas atrações em razão do defeito de uma das câmeras, impedindo que os programas fossem transmitidos do mesmo modo que foram planejados e ensaiados, exigindo grande esforço de artistas e técnicos.

Segundo Simões (1986, p. 21) o problema em uma das câmeras, atrasou o início das atividades em mais de uma hora e meia. Mas não há informações, no Diário de S. Paulo, que confirmem esta afirmação. Em diferentes edições, nas reportagens e em seções fixas como "Cidade do Rádio" e "Rádio e TV", publicou-se que a cerimônia de inauguração começou às $17 \mathrm{~h}$, como havia sido planejada e o show de abertura iniciou-se logo após às $21 \mathrm{~h}$. Em entrevista à revista Época Online, em 18 de setembro de 2010, Lolita Rodrigues, que cantou o hino da TV na estreia da PRF-3-TV, disse que uma das câmeras parou de funcionar sem motivo aparente, e que Cassiano Gabus Mendes iniciou a transmissão com apenas uma delas. 


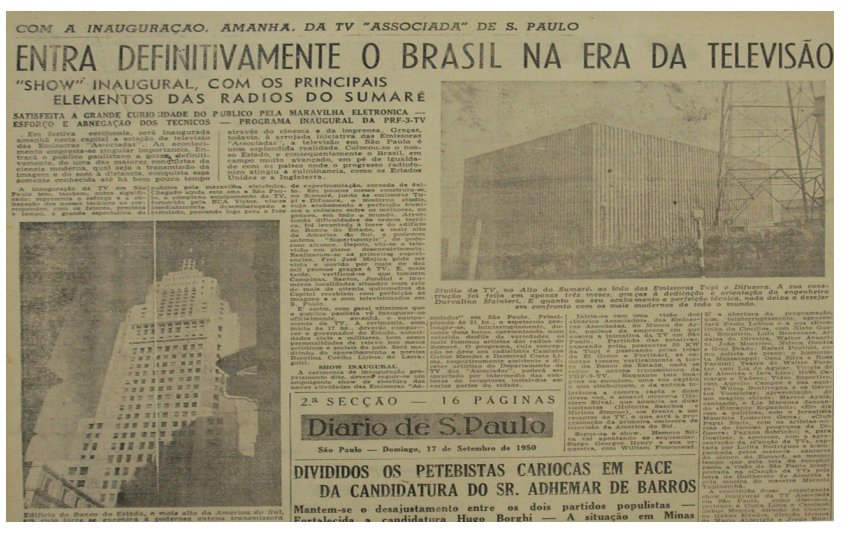

Fig. 07: Reportagem com detalhes da cerimônia de inauguração e do show de abertura. "Entra definitivamente o Brasil na era da televisão" (DSP, 17/09/1950)

Como parte das festividades comemorativas da inauguração da PRF-3-TV, a direção das Emissoras Associadas também ofereceu um banquete nos salões do Jockey Clube de São Paulo.

\section{Programação (setembro a dezembro de 1950)}

Enquanto os técnicos finalizavam a montagem do equipamento de TV na capital paulista, os diretores da PRF-3-TV começaram a preparar uma série de programas gravados. Em 23 de julho de 1950, Eliézer Burla informava, em sua coluna no Diário de S. Paulo, que as associadas paulistas pretendiam preparar "uma série intensiva de shorts cinematográficos e sketches de TV", acrescentava que a TV Tupi já tinha mais de quarenta programas prontos e que os trabalhos continuavam pela noite adentro, sem parar, há mais de três semanas.

A equipe da PRF-3-TV - elenco de artistas, a equipe de direção e de produção dos programas - era formada por profissionais que trabalhavam nas rádios Tupi e Difusora (Emissoras Associadas). Artistas internacionais que visitavam a "Cidade do Rádio" também eram convidados a se apresentarem na televisão.

Em razão da falta de experiência dos profissionais e de poucos modelos de programas de televisão (apenas realizados fora do Brasil), o que se via nos primeiros meses da TV Tupi, era uma cópia dos programas feitos nas rádios Tupi e Difusora. Entretanto, essa aproximação entre a televisão e o rádio era vista pelos diretores da PRF-3-TV, de forma positiva: "Os radio-ouvintes têm, assim, oportunidade de conhecer, através da televisão os seus astros preferidos, atuando em audições plenas de bom humor, ritmo e sequências várias onde a política, o canto, e a poesia se juntam num entretenimento dos mais completos (...)”. (DSP, 30/09/1950).
Ao contrário das transmissões experimentais regulares, em que todos os programas exibidos eram gravados, a maior parte das transmissões realizadas após a inauguração oficial, era ao vivo. Segundo Álvaro de Moya (Apud: SIMÕES, 1986, p.19), o principal motivo era a inexistência de uma indústria cinematográfica no Brasil que pudesse alimentar a sua programação. Os poucos programas gravados eram capitados em películas no formato de $16 \mathrm{~mm}$. Um exemplo era a transmissão de algumas edições do primeiro telejornal da TV brasileira ${ }^{8}$, "Imagens do Dia", apresentado por Ruy Resende e Paulo Salomão.

Nos três primeiros meses de atividades da TV, as atrações eram transmitidas de segunda a sábado, principiando às 20 horas. Com duração de aproximadamente uma hora e meia, cada edição apresentava entre seis e sete atrações. Neste período, uma característica da programação da $P R F-3-T V$ era os frequentes atrasos - na abertura e antes de cada programa - que, segundo Mário Fannuchi (1996, p. 19), aconteciam devido à ausência de experiência em fazer televisão e a fraca estrutura de equipamentos e mão de obra.

Nove dias após a inauguração definitiva da PRF3-TV, o Diário de S. Paulo passou a publicar, na capa, a programação diária das transmissões. Como ainda não havia uma grade de programação com dias e horários fixos, esta era a forma dos telespectadores saberem antecipadamente quais atrações seriam exibidas naquele dia. Nos três primeiros meses de transmissões regulares, "Imagens do Dia" era o único programa apresentado em todas as edições, em geral, encerrando a programação da PRF-3-TV.

\section{TELEVISÃO}

Programa de hoje da PRF3-TV (televisăo), a partir das 20 horas:

1) GEORGES HENRY E SEU SHOW ANTARCTICA (com William Fourneaud)

2) "THE GREAT GEORGE" (Prestidigitação e magica)

3) TELE-FILM

4) "ALBUM DE MUSICA" (produção de Aurelio Campos, com Esterzinha Borges, Nelson Novais, Marisa, Vadéco, Rosa Pardini, Marcos Ayala, Lia Marques, Miriam Simone e Iara Lins

5) DESENHO ANIMADO

6) "IMAGENS DO DIA" (reportagem de Rui Rezende e Paulo Salomão)

Fig. 08 Lista de programas exibidos pela PRF-3-TV (DSP, 24/10/1950)

8 A primeira edição foi em 19 de setembro de 1950.

\section{9


A partir de 15 de outubro de 1950, a TV Tupi passou a ter programação aos domingos, com transmissões de jogos de futebol. A primeira partida televisionada foi entre São Paulo e Palmeiras, no Estádio do Pacaembu.

O primeiro filme de longa metragem transmitido pela PRF-3-TV foi o italiano "Trágica perseguição", em 24 de setembro de 1950. Já a primeira peça teatral foi "A vida por um fio", transmitida ao vivo na noite de 29 de novembro do mesmo ano.

Uma característica da TV Tupi, neste período, era a programação de sexta-feira, dedicada inteiramente ao público mirim ${ }^{9}$ Os programas mais frequentes eram: "Caixa de brinquedos" com Homero Silva e os artistasmirins do Clube Papai Noel, "Dois Malucos na TV" com Fuzarca e Torresmo, "Suzana Rodrigues e seus bonecos" (fantoches), "7 instrumentos" com Mister Broni.

O perfil da programação da televisão em 1950 era bastante variado, composto por programas como: reportagens ("Imagens do dia", de Rui Rezende e Paulo Salomão); Vídeo político com Maurício Loureiro Gama (comentários das eleições); apresentações musicais (orquestras, cantores do rádio, instrumentistas, etc); dança; documentários; lutas (Ring na TV, Hercules e seus lutadores), desenho animado; telefilme; mágica; poesia; humor (Rancho Alegre com Mazzaroppi); Folclore com Alceu Maynard Araújo; Teatro de Walter Forster; entre outros.

\section{Algumas considerações}

Não foi por acaso que Chateaubriand escolhera o Diário de S. Paulo como principal meio de comunicação impresso para informar à população de São Paulo e região sobre a chegada da televisão. Além de tiragem considerável, imprimindo aos domingos mais de 140.000 jornais, tratava-se de veículo voltado para a elite, a mesma que teria condição de comprar um caro receptor de televisão para assistir, do conforto do lar, as emissões da PRF-3-TV.

9 Segundo Mário Fanucchi (1996, p.152), logo que a TV Tupi foi ao ar, as crianças se mostraram encantadas com este novo veículo. E não apenas pelos programas voltados exclusivamente para elas, como os desenhos animados, mas se interessavam por tudo que era transmitido. "Era uma admiração incondicional, sem a mínima restrição (...)".Esse interesse pela TV criou um problema para as famílias, já que as crianças passaram a se recusar a ir dormir antes do fim da programação. Foi neste contexto, após muitas cartas enviadas pelos pais fazendo um apelo aos dirigentes da TV, que foi criado um jingle, veiculado diariamente, às $21 \mathrm{~h}$, com a seguinte informação: "Já é hora de dormir... Não espere mamãe mandar. Um bom sono pra você e um alegre despertar!".
Os textos e as imagens publicados no Diário de S. Paulo, em certa medida, permitem entender diversas etapas que deram origem à televisão brasileira: da compra do equipamento à transmissão regular. O material recolhido pode ser dividido em dois grandes blocos: antes das transmissões experimentais e após elas. No primeiro bloco verifica-se o desejo em explicar ao público o que era uma emissora de televisão - suas características e possibilidades; provocando a formação de um imaginário sobre o novo meio de comunicação. No segundo, buscam reproduzir "a realidade da TV" em São Paulo, abordando, sobretudo, o pioneirismo e o êxito das transmissões em longa distância.

Por fim, deve-se ressaltar que a televisão chegou ao Brasil através da iniciativa privada, como parte de um conglomerado de comunicação: de jornais, de revistas e de emissoras de rádios espalhados em várias regiões do país. O jornal, em particular o Diário de S. Paulo, teve papel importante ao publicar informações sobre a implantação da PRF-3-TV em São Paulo, um veículo desconhecido da maioria da população, ajudando a formar um imaginário em torno da televisão; e também, por publicar a programação da emissora - isto porque, há poucos registros audiovisuais do período formativo da televisão brasileira, em particular, da TV Tupi de São Paulo.

\section{Referências bibliográficas:}

FANUCCHI, Mário. Nossa próxima atração: o Interprograma no canal 3. São Paulo: Edusp,1996.

MATTOS, Sérgio. A televisão no Brasil: 50 anos de história (1950-2000). Salvador: PAS-Edições Ianamá, 2000.

MORAIS, Fernando. Chato: o rei do Brasil. $3^{\mathrm{a}}$ ed. São Paulo: Companhia das Letras, 1994.

NUNES, Mônica de Fátima Rodrigues. Paulicéia literária: páginas e suplementos literários em jornais paulistanos. Tese. Universidade Metodista de S. Paulo, São Bernardo do Campo/SP, 2007.

SIMÕES, Inimá. “TV à Chateaubriand". In: COSTA, A.H. SIMÕES, I. F. \& KEHL, M. R. Um país no ar. São Paulo: Brasiliense, 1986.

\section{Periódicos:}

BURLA, Eliézer. "Crônica Dominical”. Suplemento. Diário de S. Paulo, 23 jul 1950. p.11. 
set 1950, p.8.

CHATEAUBRIAND, Assis. "Uma TV que vai serra -abaixo, serra-acima". Diário de S. Paulo, São Paulo, 31 agosto 1950, capa.

. "O sinal da televisão do céu de Piratininga”. Diário de S. Paulo, São Paulo, 22 set 1950, capa.

"Uma conquista do nosso tempo: cinema, teatro, rádio e mais o jornal combinados". Diário de S. Paulo, São Paulo, 02 fev 1950.

"Serão cada vez mais acessíveis os preços dos receptores de televisão". Diário de S. Paulo, 09 fev 1950.

“Não apenas 'ouvir', mas 'ver' novelas". Diário de S. Paulo, São Paulo, 12 fev 1950.

"Televisionado Frei José Mojica para o povo". Diário de S. Paulo, São Paulo, 08 jul 1950.

"Programas de televisão em S. Paulo para dentro de poucos dias". Diário de S. Paulo, São Paulo, 23 jul 1950.

"Entregue a São Paulo a TV Associada". Diário de S. Paulo, São Paulo, 19 set 1950.

"Dança de câmera na TV". Diário de S. Paulo, São Paulo, 30 set 1950.

"Firma varejista de tecidos assina contrato com a TV". Diário de S. Paulo, São Paulo, 29 dez 1950.

60 anos de TV. "Lolita Rodrigues Cantou o hino da TV brasileira". Revista Época Online, 27 de set 2010. Disponível em: http://colunas.revistaepoca.globo.com/60anos$\operatorname{detv} / 2010 / 09 / 18 /$ lolita-rodrigues-ela-cantou-o-hinoda-tv-brasileira/ [Consultado a: 01 de julho de 2012].

“Agora, a televisão". Cinearte, Rio de Janeiro, 29. jul 1931, p.20.

Recebido: 03/10/2012

Aprovado: 05/03/2013 